\title{
Editor's Desk
}

\section{K. S. Gopinath}

Published online: 7 February 2013

(C) Indian Association of Surgical Oncology 2013

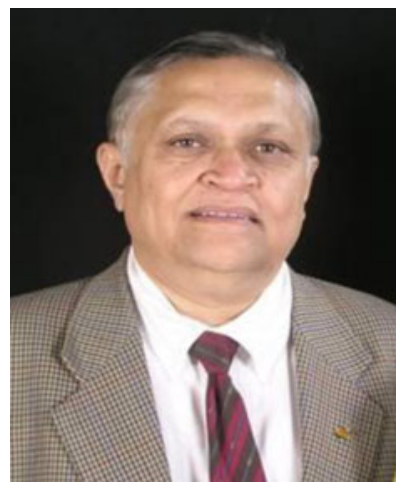

\section{Season's greeting and happy new year.}

The years have gone by, has been expectedly challenging, it took our collective efforts to weather many a crisis to the year gone by with a good note.

There is an overall Spirit of good will, give and take amongst our members and it shall be our primary responsibility to ensure that the journal improves by leaps and bounds in the year ahead.

Last year witnessed increase in the online submission of articles compared to the previous years. In fact for a journal in infancy stages, the response from the oncology community is outstanding.

The accreditation by Pub -Med, Pubmed Central, Google scholar, EMBASE and Summons by serial solution. It has an added advantage and use of the journal and clicks on the website is record one.

The articles to the journal were submitted not only from this country but also across the globe, I thank all the authors and reviewer's who contributed to this journal and make it a very useful to all.

We shall attempt embark, on significant upgrades in publication and our aim is to publish information providing robust, reputable and pioneering new solutions for the modern oncological work force.

This year we will publish special issue on thoracic oncology.

The Indian cancer congress will be organized in New Delhi in November 2013; the editorial board has decided to publish the abstract of scientific presentation. The editorial board has nominated Dr. Chandra Arre from U.S.A and Dr. David Rew from U.K. as international advisor to the journal committee. Both of them have vast experience that will help the journal to progress in the right direction.

I thank the entire sponsor's of IJSO and publisher Springer India PVT LTD, who took the responsibility to do this job of publication.

I am humbled and overwhelmed with all the support, love and affection and for the trust. It shall be my endeavours to continue efforts to take this journal forward.

With best wishes for 2013 . 